\title{
An Investigation of Thai Students' English Language Problems and Their Learning Strategies at English Study Program of Teacher Training and Education Faculty of Riau Islamic University
}

\author{
Sri Wahyuni ${ }^{1}$, Muhammad Ilyas ${ }^{2}$ \\ ${ }^{1}$ Islamic University of Riau \\ email:wahyunis@edu.uir.ac.id \\ ${ }^{2}$ Islamic University of Riau \\ Email:m.ilyas@edu.uir.ac.id
}

\begin{abstract}
The purpose of this study was to investigate the English language problems and learning strategies. The study employed a survey design which involved administering questionnaires of rating scales, using Rubin, J., \& Thompson, I. (1994) and Rebecca Oxford (1990) Strategy Inventory for Language Learning (SILL), to measure English language problems and language learning strategies from 10 Thai students of English Study Program of Teacher Training and Education Faculty at Riau Islamic University. The result of this study revealed that the most serious problem of Thai students in English Language Learning is listening and writing skills while reading skill is the least problem. Another big problem involved being unable to write an essay within limited time and always have a listening problem. Beside, the problem least mentioned is unable to understand classroom lectures in English. All Participant reported a high frequency use of strategy on the SILL. The participants reported using social strategies most frequently and metacognitive strategies least frequently but in medium range. The most frequently used strategies involved asking lecture or classmate for helping. Not trying guess if they do not fully understand what is being said was the least frequently used.
\end{abstract}

Keywords: Correlation, English Language Problems, Learning Strategies

\begin{abstract}
Abstrak
Tujuan dari penelitian ini adalah untuk menyelidiki masalah-masalah berbahasa Inggris dan strategi-startegi belajar bahasa. Penelitian ini menggunakan desain survei yang menggunakan kuesioner yang diadopsi dari Rubin, J., \& Thompson, I. (1994) dan Rebecca Oxford (1990) mengenai Strategy Inventory for Language Learning (SILL). Kuesionerkuesioner tersebut untuk masalah-masalah berbahasa Inggris dan strategi-startegi belajar bahasadari 10 mahasiswa Thailand Program Studi Bahasa Inggris dari Fakultas Keguruan dan Ilmu Pendidikan di Universitas Islam Riau. Hasil penelitian ini menunjukkan bahwa masalah yang paling serius dari mahasiswa Thailand di Program Studi Pendidikan Bahasa Inggris adalah belajar menyimak dan keterampilan menulis sedangkan kemampuan membaca adalah masalah yg tidak begitu problematik. Masalah menulis yang paling problematik adalah tidak mampu untuk menulis sebuah esai dalam waktu yang terbatas dan selalu memiliki masalah mendengarkan. Selain itu, masalah berbahasa yang tidak terlalu problematik adalah tidak dapat memahami kelas kuliah dalam bahasa Inggris. Semua responden berada pada tingkat frekuensi tinggi terhadap strategi yang diadopsi dari SILL. Responden menggunakan strategi sosial yang paling sering dan strategi metakognitif juga paling sering tetapi dalam frekuensi medium. Strategi yang berkaitan dengan sosial yang
\end{abstract}


sering digunakan adalah terlibat dalam meminta bantuan kuliah kepada teman sekelas ataupun dosen. Tidak mencoba menebak jika mahasiswa tidak sepenuhnya memahami apa yang dikatakan adalah strategi yang paling jarang digunakan.

Kata Kunci: Korelasi, Masalah-masalah Berbahasa Inggris, Strategi-strategi Belajar

\section{INTRODUCTION}

There are many factors that influence in learning a foreign language. One of things that must be considered is strategies. Schemeck (1988) states that strategy is the implementation of a set of procedures (tactics) for accomplising something and learning strategy is a sequence of procedures for accomplishing learning. Weinstein and Mayer (1986) also propose learning strategies as "behaviours and thoughts that a learners engages in during learning and that are intended to influence the learner's encoding process. More specifically, Rigney (1978) defines learning strategies as "cognitive strategy" which is "used to signify operations and procedures that the student may use to acquire, retain, and retrieve different kinds of knowledge and performance".

Furthermore, Rubin (1975) defines strategies as the techniques or devices, which a learner may use to acquire knowledge. In language learning, Rubin (1987) proposes that language learning strategies are strategies which contribute to the development of language system which the learner contructs and affect learning directly. She also suggests that language learning strategie include any set of operations, steps, plans, routins used by the learners to facilitate the obtaining, storage, retrieval, and use of information.

Similarly, O'Malley et al (1985) defines language learning strategies as any set of operations or steps used by a learner that will facilitate the acquisition, storage, retrieval, or the use of information. Next, Chamot (1987) also defines language

J-SHMIC, Vol 3, No 2, August 2016 learning strategies as techniques, approaches or deliberate actions that students take in order to facilitate the learning and recall of both linguistics and content area information. She proposes that some language learning strategies are observable, but some may not be observable. In cognitive perspectives, O'Malley and Chamot (1990) view language learning strategies as the special thoughts and behaviors of processing information that individuals use to help them comprehend, learn, or retain new information.

Language learning strategies have been categorized by many experts. However, most of theirs attempts to classify language leraning strategies reflect more and less the same language learning startegies without any radical changes. O’Malley (1985) divides language learning startegies into three main subcategories: Metacognitive Strategies, Cognitive Strategies, and Socioaffective Strategies. Next, Rubin (1987) makes the distinction between strategies contributing directly to learning and those contributing indirectly to learning. According to Rubin, there are three types of strategies used by learners that contribute directly and indirectly to language learning. According to Stern (1992), there are five main language learning strategies. These are; management and planning strategies; cognitive strategies; communicative-experential strategies; interpersonal strategies; and affective strategies.

In addition, Oxford (1990) divides language learning strategies into two main 
categories; direct and indirect strategies which are also subdivided into six classes. Direct strategies, which involve the new language directly, are divided into memory, cognitive, compensation strategies. As oxford says all direct strategies require mental processing of the language. Memory strategies entail the mental process for storing new information in the memory and for retrieving them when needeed. Theses strategies consist of four sets that include; creating mental linkages, applying images and sounds; reviewing well; and employing action. Then, cognitive strategies entail conscious way of handling the target language and fallinto four sets which include; Practicing; Receiving and sending messages; Analysing and reasoning; Creating structure input and output. The last of direct strategies proposed by oxford is compensation strategies. They enable learners to use the language either speaking or writing despite knowledge gaps. These strategies are divided into two sets; guessing intelligently; and overcoming limitations in speaking and writing. These strategies arre employed by the learners when facing a tomporary breakdown in speaking or writing.

Indirect strategies include metacognitive, affectice, and social strategies. Indirect strategies provide indirect support for language learning by using different strategies such as focusing, arranging, evaluating, looking at the chances, and lowering the anxiety. Firstly is metacognitive strategies. These strategies enable the learners to control their own cognition. They are strategies which entail overviewing and linking with material already know, paying attention, delaying speech production, organizing, setting goals and objectives, planning for a language task, looking for practice chances, selfmonitoring, and self-evaluating. Next, affective strategies, these assist students to manage their emotions, motivations, and attitude associated with learning. They can

J-SHMIC, Vol 3, No 2, August 2016 be achieved through lowering anxiety, encouraging oneself, and taking emotional temperature. The last is social strategies. These strategies facilitate the students to learn langauge through interactions with others. Asking question, cooperating, and empathizing with other are including into sets of social strategies.

According to fedderholdt (1997) in Feng (2005), the language learners capable of using a wide variety of language leraning strategies appropriately can improve his language skills in a better way. Beside, Lessard-Clouston (1997) states that language learning strategies contribute to the development of the communcative competence of the student. Oxford (1990) also states that language learning strategies are specially important for language learning because they are tools for active, self-directed movement, which is essential for developing communicative competence. In other words, language learning strategies is as indicator of how the learners face and solve the problems in learning language and as tools which is very crucial to enhance students' communicative competence.

To be competent in English, students need to acquire four language skills including listening, speaking, reading, and writing (Rahimi, 2008; Lee, 2003; Anderson, 2005; Green \& Oxford, 1995; and O'Malley \& Chamot, 1990). These four skills is called macro-skills. This is contrast to the micro-skills, which are things like grammar, vocabulary, pronunciation, spelling, etc,. This knowledge is frequently called competence and its realization is described as performance. In the process of learning itsself, the students will have listening, speaking, reading, and writing subject that have its standard score to achieve the goal of each subjects. In other hands, the students could be competent in acquring language if they were able to achieve each indicators of language skills.

In relation with language learning strategies and to be successful English 
language students, students need to be in control of the way they learn by considering the procedure and strategies that most effective to use. Students who emphasized the importance of using the English language would often consider which strategies are appropriate to use with them in different learning situation. Each strategy may not be appropriate in all language learning skills; listening, speaking, reading and writing. Why it is not difficult for somebody people to communicate in English? What are strategies do they use? If students intend to use those strategies, they may be able to set their goal, identify problems and find appropriate solution. Finally, they can improve and achieve their English language learning.

There were many studies investigating Thai students who faced English language problem in a colllege for instance; Juthamas Thongsongsee (1998) investigated linguistic and cultural difficulties encountered by Thai student graduates from American universities; Patcharaporn Songsangkaew (2003) studied the language function difficulties experienced by Thai students in real situations in America; Wong (1985) examined the problems and implications of language assessment of Asian students; and Crowe'sstudy (1992) illustrated that Asian students experienced language problems in writing English. Previous studies has fostered the researcher to conduct a study in the same area but in different aspect.

In this case, Thai students who have been studying at English study program of teacher training and Education faculty faced many problems related to learning English. For instance, they were not able to respond well in a conversation using English. They maybe lacked of vocabulary or felt abundant to say something. After that, they could not arrange words to be sentences grammatically when speaking or writing. In other hands, four language skills are problematic for Thai students.
Further, with regard to the importance of language learning strategies and English language problems, the reseachers conducted a study to investigate and clarify the English language problems and how Thai students used their learning startegies. There were many experts that had discussed related to language learning strategies (Schemeck, 1988; Mayer, 1986; Rigney, 1978; Rubin, 1975; Rubin, 1978; O'Malley et al, 1985; Chamot, 1987; O’Malley \& Chamot, 1990; Oxford, 1990; and Stern, 1992). In this study, categorization of language learning strategis adopted from oxford (1990) and limit the English language problem into listening, speaking, reading, and writing (Rubin \& Thompson, 1994).

In line with the statement above, this study was attempt to answer the following two research question.

a. Research Question 1: What are the English problems perceived by Thai Students at ESP?

b. Research Question 2: How do they use learning strategies to achieve the ESP's Vision?

\section{METHOD}

The study employed a survey design which involved administering questionnaires of rating scales, using Rubin, J., \& Thompson, I. (1994) and Rebecca Oxford (1990) Strategy Inventory for Language Learning (SILL), to measure English language problems and language learning strategies from 10 Thai students of English Study Program of Teacher Training and Education Faculty at Riau Islamic University. Further, The objectives of the research aims at studying and answering two research questions. First, what are English problems perceived by Thai students at ESP? Second, how do they solve their problems to achieve ESP's vision?, to answer the two research questions in this study, descriptive statistics analyses was 
carried out. This research conducted at English Education Study Program, Teacher Training and Education Faculty, Islamic University of Riau. It started on November 2015 to March 2016.

Furthermore, to answer the research questions, a questionnaire was addressed to the students. the questionnaire is divided into three sections. The first section is students' demographic data.It concerns with individuals and academic characteristics, for instance, age,gender, fields of study, and prior experience in English language learning. The second section is designed to collect students' problems to reveals the English learning probelms. The English problems are considered in 4 language skills; listening, speaking, reading, and writing according to Rubin \& Thompson (1994). The last section is aimed to find students' solution. This section attempts to consider the strategies learning as a solutions that participants employ to achieving the target goal. The questionnaire is designed according to Oxford (1990) on six categories of language learning strategies including cognitive strategies, metacognitive strategies, memory-related strategies, compensantory strategies, affective strategies, and social strategies.

In addition, the questionnaire was verified by Dr. Rugaiyah, M.Pd., Dr. Hj. Sri Rejeki, M.Si., Dr. Sri Yuliani, M.Pd to check the effectiveness of the questionnaire before employing in this study. Then, to figure out the validity and reliability of the questionnaire, the researhcers did trial test. The trial test of the questionnaire were administred to Thai students who ever studied at English Study Program of Teacher Training and Education Faculty for several times. After getting the result of trial test, the researchers tested the questionnaire by using SPSS 19 to get the valid items of questionnaire and its reliability.

In order to acquire a sample that would be representative of Thai Students, ten Thai students who study at English Study Program of Teacher Training and Education Faculty were participants incurrent research. To understand the variables in this study, descriptive statistics analyses were carried out.

The questionnaire computed for means and standard deviation (SD) in order to reveal the english problems perceived by Thai students. The english problems classified into 5 levels; always $=5$, usually $=4$, occasionally $=3$, rarely $=2$, and never $=1$.

In reporting problems and frequency of use in learning strategies, SILL developed by Oxford (1990) provides the basic framework to understand the mean score on students' SILL, which has a scale range of 1-5:

Intrepretation data of English language problems:

$\begin{array}{lll}\text { Low } & \text { Always have problems } & 1.0 \text { to } 1.4 \\ & \text { Usually have problems } & 1.5 \text { to } 2.4 \\ \text { Medium } & \text { Sometimes have problems } & 2.5 \text { to } 3.4 \\ \text { High } & \text { Seldom have problems } & 3.5 \text { to } 4.4 \\ & \text { Never have problems } & 4.5 \text { to } 5.0\end{array}$




\begin{tabular}{|c|c|c|c|c|}
\hline \multirow[b]{2}{*}{ High } & \multicolumn{4}{|c|}{ Intrepretation data of frequency and learning strategies: } \\
\hline & Always or almost always use & .5 to 5.0 & Usually use & 3.5 to 4.4 \\
\hline Medium & Sometimes use & 2.5 to 3.4 & & \\
\hline Low & Generally not use & 1.5 to 2.4 & & \\
\hline & Never or almost never use & 1.0 to 1.4 & & \\
\hline
\end{tabular}

\section{FINDINGS AND DISCUSSION}

The finding of this study will be discussed into three parts comprising demographic data, english language problems, and strateges use. The first part is students' demographic data. Based on the demographic data of participants, most of participants $(40 \%)$ were aged 21 . The number of female participants was 7 (70\%) and male was $3(30 \%)$. It also provided information on the break down of the participants by period of studying English language. Most of the participants $(70 \%)$ studied between 3 up to 4 years. all of participants have ever been studying english since junior high school until university. Also, they ever studied abroad that is in Indonesia only. Furthermore, the

data indicates that $80 \%$ rated their proficiency with others students in class at the poor level. All of participants enjoy studying English. In addition, they learn others language including Thai, Malay, Indonesia, Jawi, and Arabic. For learning english, the data indicated that Thai students were interested the on language only.

The second part is the data related to English language problems the most and the least problematic were faced by the Thai students. This part is the answer of the first question of this research, that is "What are the English problems perceived by Thai Students at ESP?". To see the clearly data, the researchers present in the following table.

Table 1 The three most problematic English tasks

\begin{tabular}{|l|c|c|c|}
\hline \multicolumn{1}{|c|}{ Strategy } & Means & $\begin{array}{c}\text { Problem } \\
\text { Category }\end{array}$ & $\begin{array}{c}\text { Interpreta } \\
\text { tion }\end{array}$ \\
\hline I never have a listening problem & 1,4 & Listening & Low \\
\hline $\begin{array}{l}\text { I am able to write an essay within } \\
\text { limited time }\end{array}$ & 1,6 & Writing & Low \\
\hline I never have a writing problem & 1,6 & Writing & Low \\
\hline
\end{tabular}

As shown in table 1 , the problematic English tasks fell at the degree of low level which means the participants always have problems with listening and writing. Moreover, the most interesting finding is the two English tasks in writing skills problems employed most by the participants in the currentstudy; unable to write an essay within limited time and always have a writing problem with means of 1,6 . 
Table 2 The three least problematic English Tasks

\begin{tabular}{|l|c|c|c|}
\hline \multicolumn{1}{|c|}{ Strategy } & Means & $\begin{array}{c}\text { Problem } \\
\text { Category }\end{array}$ & $\begin{array}{c}\text { Interpret } \\
\text { ation }\end{array}$ \\
\hline $\begin{array}{l}\text { I understand the tone of voice of } \\
\text { speakers }\end{array}$ & 2,7 & Listening & Medium \\
\hline $\begin{array}{l}\text { I feel comfortable in talking with } \\
\text { lecturer in the classroom by using } \\
\text { English }\end{array}$ & 2,6 & Speaking & Medium \\
\hline $\begin{array}{l}\text { I am able to understand classroom } \\
\text { lectures in English }\end{array}$ & 2,5 & Listening & Medium \\
\hline
\end{tabular}

As displayed in table 2, listening and speaking fell at medium English language problems level. The most interesting finding is the two problematic English tasks in listening employed least by the participants in the current study; do not understand the tone of voice of speakers and unable to understand clasroom lectures in
English.

Further, to answer the second research question that is "How do they use learning strategies to achieve the ESP's Vision?". to see clearly the data related to learning strategies the most and the least used by the Thai students, the researchers present in the following table.

Table 3 The six most frequently used strate

\begin{tabular}{|l|c|c|c|}
\hline \multicolumn{1}{|c|}{ Strategy } & Means & Strategy & Interpretation \\
\hline $\begin{array}{l}\text { I try to guess if I donot fully understand } \\
\text { what is being said }\end{array}$ & 2.4 & Metacognitive & Low \\
\hline $\begin{array}{l}\text { When I do not know how to say } \\
\text { something in English, I say something } \\
\text { else instead }\end{array}$ & 2.7 & Metacognitive & Medium \\
\hline $\begin{array}{l}\text { When I have any problem, I prefer to } \\
\text { consult with another classmate or } \\
\text { lecturers rather than Thai Friends }\end{array}$ & 2.7 & Social & Medium \\
\hline $\begin{array}{l}\text { I take every opportunity to practice } \\
\text { English }\end{array}$ & 2.8 & Cognitive & Medium \\
\hline $\begin{array}{l}\text { If I do not understand all the words i read } \\
\text { or hear, I try to keep listening/ reading } \\
\text { because I may get a clue as what was } \\
\text { meant }\end{array}$ & 2.9 & Metacognitive & Medium \\
\hline $\begin{array}{l}\text { When I write English essay, I copy the } \\
\text { patterns of others }\end{array}$ & 2.9 & Cognitive & Medium \\
\hline
\end{tabular}


As shown in table 3, four strategies; social, affective, metacognitive, and compensatory fell at medium-use to highuse range. The most interesting finding is the two social strategies employed of ten used by the participants in the current study: ask their lecturer or classmate for helping them when they don't understand their lesson, and usually ask my classmate to edit my English writing.

Table 4 The six least frequently used strategies

\begin{tabular}{|l|c|c|c|}
\hline \multicolumn{1}{|c|}{ Strategy } & Means & Strategy & Interpretation \\
\hline $\begin{array}{l}\text { I ask my lecturer or classmate } \\
\text { for helping me when I don't } \\
\text { understand my lesson }\end{array}$ & 4.1 & Social & High \\
\hline $\begin{array}{l}\text { I usually ask my classmate to } \\
\text { edit my English writing }\end{array}$ & 3.9 & Social & High \\
\hline $\begin{array}{l}\text { I talk to someone I trust about } \\
\text { my attitudes and feelings } \\
\text { concerning the English } \\
\text { language learning process }\end{array}$ & 3.8 & Affective & High \\
\hline $\begin{array}{l}\text { If I am speaking and cannot } \\
\text { think of the right expression, I } \\
\text { use gestures or switch back to } \\
\text { my own language momentarily }\end{array}$ & 3.8 & Metacognitive & High \\
\hline $\begin{array}{l}\text { I direct the conversation to a } \\
\text { topic for which i know the } \\
\text { words }\end{array}$ & 3.4 & Compensatory & Medium \\
\hline $\begin{array}{l}\text { I give myself a reward when I } \\
\text { have done something well in } \\
\text { English learning }\end{array}$ & 3.4 & Affective & Medium \\
\hline
\end{tabular}

As revealed by the table 4, three strategies; metacognitive, social, and cognitive memory fell at low-use to medium-use level. The most interesting finding is the two metacognitive strategies employed least by the participants in the current study; try to guess if they do not fully understand what is being said and when they do not know how to say something in English, they say something else instead.
In addition, in the last part, The results of correlation between English Language problems and learning strategies show that ten Thai students' reading problem was correlated with three categories strategy use; metacognitive $(\mathrm{r}=.716)$, memory $(\mathrm{r}=.802)$, and social $(\mathrm{r}=.784)$. To put it another way, participants who had reading problems employed three learning strategies; metacognitive, memory, and social strategies to solve those problems. These results were correlated

An Investigation of Thai Students' English

Language Problems and Their Learning Strategies at English Study Program of Teacher Training and Education Faculty of Riau Islamic University 
with table 3.2, reading was the least English language problems compared with Also found were significant results between strategy use and English language problems, showing that metacognitive strategies were two strategies that have correlated to two language problems; speaking $(\mathrm{r}=.767)$ and reading $(\mathrm{r}=.716)$.

Table 5. Correlations between English Language Problems and Learning Strategies

\begin{tabular}{|l|c|c|c|c|}
\hline Pearson Correlation & Listening & Speaking & Reading & Writing \\
\hline Cognitive & .190 & .533 & .456 & $.691^{*}$ \\
Sig. (2-tailed) & .599 & .113 & .185 & .027 \\
\hline Metacognitive & .257 & $.767^{* * *}$ & $.716^{* *}$ & .463 \\
Sig. (2-tailed) & .473 & .010 & .020 & .178 \\
\hline Memory & .048 & .469 & $.802^{* * *}$ & .362 \\
Sig. (2-tailed) & .895 & .171 & .005 & .304 \\
\hline Compensatory & .389 & .459 & .356 & .618 \\
Sig. (2-tailed) & .267 & .182 & .312 & .057 \\
\hline Affective & .076 & .135 & .381 & .040 \\
Sig. (2-tailed) & .834 & .711 & .278 & .912 \\
\hline Social & .000 & $.718^{*}$ & $.784^{* * *}$ & .587 \\
Sig. (2-tailed) & 1.000 & .019 & .007 & .074 \\
\hline
\end{tabular}

** Correlation is significant at the 0.01 level (2-tailed).

* Correlation is significant at the 0.05 level (2-tailed). listening, speaking, and writing.

furthermore, social strategies were also correlated to two language problems; speaking $(\mathrm{r}=.718)$ and reading $(\mathrm{r}=.784)$. The results of this study could be seen in the following table.

\section{CONCLUSION AND SUGGESTION}

Based on findings of the research, it could be concluded that the students' overall problem was slightly correlated with the frequency of strategy use. Based on the results, the participants' reading problem was correlated with three categories strategy use; metacognitive $(\mathrm{r}=.716)$, memory $(\mathrm{r}=.802)$, and social $(\mathrm{r}=.784)$. To put it another way, participants who had reading problems employed three learning strategies; metacognitive, memory, and social strategies to solve those problems. These results were correlated with reading problems compared with listening, speaking, and writing. Again, students employed three categories learning strategies; consequently, they encountered the least problems in reading skill.
The researcher also found the significant results between strategy use and English language problems, showing that metacognitive strategies were two strategies that have correlated to two language problems; speaking $(\mathrm{r}=.767)$ and reading $(\mathrm{r}=.716)$. Furthermore, social strategies were also correlated to two language problems; speaking $(\mathrm{r}=.718)$ and reading $(r=.784)$. in other words, Thai students tended to use metacognitive and social strategies to solve English language problems; speaking and reading specifically.

Moreover, based on the result of the research, the researcher would like to give suggestions that will be usefull to the course especially for English language teaching for

An Investigation of Thai Students' English

Language Problems and Their Learning

Strategies at English Study Program of

Teacher Training and Education Faculty of

Riau Islamic University 
foreign learners. The lecurers are suggested to motivate foreign learners and give the solution to overcome their problems in learning English. Metacognitive strategies were the most frequently used of Thai students. Indeed, metacognitive strategies provide a way for learners to coordinate their own learning process such as centering, arranging, planning, and evaluating. These beyond the cognitive strategies are used to provide executive control over the learning process. Also, The research writing is hopefully providing meaningfull reference for those who are interested in conducting a research in the same areas of discussion.

\section{REFERENCES}

Chamot, A. U. 1987. The learning strategies of ESL students. In A.Wenden \& J. Rubin (Eds.), Learner strategies in language learning. Englewood Cliffs, NJ: Prentice-Hall.

Chamot, A. U. 2004. Issues in Language Learning Strategy Research and Teaching. Electronic Journal of Foreign Language Teaching, 1(1):1426.

Ehrman, M. E. \& Oxford, R. L. 1989. Effects of sex differences, career choice, and psychological type on adult language learning strategies. The Modern Language Journal, 73: 1-3.

Feng, Tseng, S. 2005. Language Learning Strategies in Foreign Language Education. An interdisciplinary Journal, 49: 321-328.

Green, J. M. \& Oxford, R. L.1995. A closer look at learning strategies, L2 proficiency, and gender. TESOL Quarterly, 29 (2): 261-297.
Juthamas Thongsongsee. 1998. A study of Linguistic and cultural difficulties encountered by Thai graduated students in their use of English when studying overseas. Master Thesis, Faculty ofApplied Linguistics, Mahidol University.

Lee, K. 2003. The relationship of school year, sex and proficiency on the use of learning strategies in learning English. Asian EFL Journal, 5(4): 136.

Lessard-Clouston, M. 1997. Language Learning Strategies: An Oveview for L2 Teachers. The Internet TESL Journal, 3 (12): 1-16. Available at http://iteslj.org/ Articles/LessardCluston-Strategy. Html

Mayher, J. S., Lester, N. B. \& Pradl, G. M. 1983. Learning to writel writing-tolearn. Portsmouth. NH : Boynton/Cook Publishers.

McIntyre, P. D. \& Noels, K. 1996. Using social-psychological variables to predict the use of language learning strategies. Foreign Language Annals, 29: 373-386.

Naiman, N., Frohlich, M., Stern, H., \& Todesco, A. 1978. The Good Language Learner. Toronto: Ontario Institute for Studies in Education.

O’Malley, J. M., \& Chamot, A. U. 1990. Learning strategies in second language acquisition. Cambridge, UK:Cambridge University Press.

O’Malley, J. M., Chamot, A. U., StewnerManzanares, G., Russo, R. P., \& Kupper, L. 1985. Learning strategies used by beginning and intermediate ESL students. Language Learning,

An Investigation of Thai Students' English

Language Problems and Their Learning Strategies at English Study Program of Teacher Training and Education Faculty of Riau Islamic University 
35: 21-46.

Oxford, R. L. 2003. Language learning styles and strategies: An overview. Learning Styles \& Strategies/ Oxford, GALA: 1-25.

Oxford, R. L. 1990. Language learning strategies: What every teacher should know. NewYork: Newbury House/ Harper \& Row.

Oxford, R. L., \& Nyikos, M. 1989. Variables affecting choice of language learning strategies by university students. The Modern Language Journal, 73:291-300.

Patcharaporn Songsangkaew. 2003. The language function difficulties experienced by Thai students in real situations in America. Master Thesis, Faculty of English of Applied Arts, King Mongkut's Institute of Technology North Bangkok.

Porte, G. 1988. Poor language learners and their strategies for dealing with new vocabulary. ELT Journal, 42: 167172.

Rahimi, M., Riazi, A., \& Saif S. 2008. An investigation into the factors affecting the use of language learning strategies by Persian EFL learners. CJAL, 11(2): 31-60.

Rigney, J. W. 1978. Learning strategies: A theoretical perspective. In H. F. O’Neil, Jr. (Ed.), Learning Strategies. NY: Academic.

Rossi-Le, L. 1995. Learning style and strategies in adult immigrant ESL students. InJ. M. Reid (ed.), Learning styles in the ESL/ EFL classroom. Boston: Heinle \& Heinle.
Rubin, J. \& Thompson, I. 1994. How to be a more successful language learner: toward learner autonomy. (2 $2^{\mathrm{nd}} \mathrm{ed}$.). Bonton : Heinle \& Heinle Publishers.

Rubin, J. 1975. What the "good language learner" can each us? TESOL Quarterly, 9: 41-51.

Rubin, J. 1987. Learner strategies: Theoretical assumptions, research history and typology. In A.Wenden \& J. Rubin (Eds.), Learner strategies in language learning (pp. 15-30). Englewood, NJ: Prentice/ Hall International.

Schemeck, R. R. (Ed.).1988. Learning strategies and learning styles. NewYork, NY: Plenum Press.

Stern, H. H. 1975. What can we learn from the good language learner? Canadian Modern Language Review, 31: 304318.

Stern, H. H. 1992. Issues and Options in Language Teaching. Oxford: OUP.

Vann, R. J. \& Abraham, R. G. 1990. Strategies of successful learners. TESOL Quarterly, 24: 177-198.

Weinstein, C. E., \& Mayer, R. E. 1986. The teaching of learning strategies. In M. C. Wittrock (Ed.), Handbook of

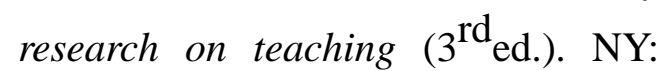
Macmillan.

Zare, P. 2010. An Investigation into Language Learning Strategy Use and Gender among Iranian Undergraduate Language Learners. World Applied Sciences Journal, 11(10): 1238-1247.

An Investigation of Thai Students' English Language Problems and Their Learning Strategies at English Study Program of Teacher Training and Education Faculty of Riau Islamic University 